\title{
Impact of Corporate Social Responsibility Disclosure to Stockprice of Banking and Mining Industry Listed at Indonesia Stock Exchange (IDX)
}

\author{
Solihin, Etty Murwaningsari \\ willy.arafah@gmail.com
}

\begin{abstract}
This research is purposed to determine the influence of CSR disclosure on stock price of banking and mining companies that listed at Indonesia Stock Exchange (IDX). There are two models of this research, the first model without control variable BETA and PBV. And the second model included control variable BETA and PBV. BETA is proxy of risk and PBV is proxy of growth.This research was conducted on 30 mining and banking companies that listed in Indonesia Stock Exchange (IDX) for the period 2006-2007. The methodology research in this research is purposive sampling. Data analysis methods used Pearson for validity test. P-P Plot for normality test, Variance Inflation Factory (VIF) for muticollinearity test, LM-test for autocorrelation, and Glejser for heterrocedacity test. T-test and F-test was used to test hypothesis. The result of this research is in the first model (without control variable BETA and PBV), CSRI disclosure, Unexpected Return (UE), interaction between CSRI \& UE which is not influenced by CAR of mining and banking companies that listed at IDX. The second model (included control variable BETA and PBV) indicated that CSRI disclosure, Unexpected Return (UE), interaction between CSRI \& UE, Price to Book Value (PBV), BETA, interaction BETA \& PBV which is not influenced by CAR of banking and mining companies that listed at IDX.
\end{abstract}

Keywords: corporate social responsibility disclosure, earning respond coefficient (ERC), price to book value (PBV).

\section{INTRODUCTION}

Various researches indicate that the number of companies conducting disclosure or implementation of corporate social responsibility (CSR) is getting increased. A lot of companies are getting aware of the importance of application of corporate social responsibility (CSR) as part and strategy of business. Global survey for the Economist Global Intelligence unit indicates that $85 \%$ of senior executives and investors from various organizations have made corporate social responsibility (CSR) as main consideration in making decision. Although corporate social responsibility is still compulsory in character, but it can be said that almost all companies as available in Indonesia Stock Exchange have disclosed corporate social responsibility (CSR) in their annual report in various contents as it is forwarded by Sayekti (2006). The company is getting more conscious that the company survival also depends on company relationship with its community and environment where the company is operating. This matter is in line with legitimacy theory which states that company has contract with the community for conducting its activities based on the values of justice, and how the company is responding to various groups of interest for legitimizing the company action Tilt (1994). In Indonesia, CSR is stated in Law of Limited Liability Company No. 40 of 2007. In the Article under title the Competitive Advantage of Corporate Philanthropy as contained in Harvard Business Review of 2003, Michael E. Porter and Mark R Kramer said, so far the objective of economy and social tends to be seen from the viewpoint which is different and contradictory to each other. The company cannot be separated from the surrounding environment because basically the company really defends on the location where it is operating. The opinion of Milton Friedman 
Impact of Corporate Social Responsibility Disclosure to Stockprice of Banking and Mining Industry Listed at Indonesia Stock Exchange (IDX)

which said that the main objective of corporation was to merely acquire profit was getting left out. In reverse, the concept of triple bottom lines (profit, planet, and people) which become the idea of John Elkington is getting into mainstream of business ethics. Profit is believed as main information as presented in financial report of Lev Company (1989). The question is how far the advantage of profit and loss of the user of financial report has become important matter, both for the researcher, practitioners and also authorities of policy makers. A lot of models of equity earnings which are possibly influenced by assumption of calculation and also manipulated possibilities as conducted by company management, so that it is required other information beside profit for predicting the return of company share. It is found some matters which have caused marketresponses which are varied against profit, namely it is persistency of profit, beta, company capital structure, profit quality, growth opportunities, and informativeness of price (Scott, 2000). The value of earning response coefficient (ERC) is predicted higher if the company profit is more persistent in future. Likewise, if the quality of profit is getting better, then it is predicted the value of earning response coefficient (ERC) will be getting higher. Beta reflects systematic risk. Investor will evaluate current profit for predicting profit and return in future. If such future return is getting more risks, then the reaction of investor against unexpected earnings of company is getting lower. In other words, if Beta is getting higher, then ERC will be getting lower (Scott, 2000). The company capital structure also has influence against Earning Response Coefficient (ERC). Profit increase (before interest) for company of high levered has ERC which is lower as compared to the company of low levered (Scott, 2000). The company having growth opportunities is expected to provide high profitability in future, and it is expected more persistent profit. As such, ERC will be higher for company which has growth opportunities Scott (2000). It is found several factors which influence the company share price in the stock exchange, indication from the market response against company share is indicated with the presence of Earning Response Coefficient (ERC) which measuring is made by proxy with CAR. Other factor also influences the market response against profit is informativeness of that market price itself. The higher informativeness of share price, then the content of information from profit is getting reduced. Therefore, ERC will be getting lower if the inromativeness of share price is increasing or if the size of company is increasing, Scott (2000). Based on the above description, the hypothesis as submitted in this research is as described below.

\section{Model 1 (without Control Variable)}

Ha1: UE and CSRI has an significant influence on CAR without control variable (BETA and price-to-bookvalue (PBV) ratio

Ha2: UE (unexpected earning) has an significant influence on CAR without control variable (BETA and price-to book-value (PBV) ratio

Ha3: CSRI (corporate social responsibility index) has an significant influence on CAR without control variable (BETA and price-to-book-value (PBV) ratio.

\section{Model 2 used Control Variable (BETA and PBV)}

Ha4: UE and CSRI has an significant influence on CAR by including control variable (BETA and price-to-bookvalue (PBV) ratio

Ha5: UE (unexpected earning) has an significant influence on CAR by including control variable (BETA and price-to-book-value (PBV) ratio

Ha6: CSRI (corporate social responsibility index) has an significant influence on CAR by including control variable (BETA and price-to-book-value (PBV) ratio.

American Research Journal of Business and Management

Page 2 
Impact of Corporate Social Responsibility Disclosure to Stockprice of Banking and Mining Industry Listed at Indonesia Stock Exchange (IDX)

\section{MeThODOLOGY}

\section{Dependent Variable: Cumulative Abnormal Return (CAR)}

Dependent variable in this research is Cumulative Abnormal Return (CAR) which is calculated daily for the period of 15 months, namely from January 1, 2006 up to March 31, 2007. The measuring of abnormal return in this research is using market adjusted model which assumes that the measuring of expected return of the best measuring of company share expected return is market index return like the one as disclosed by Pincus (1993). Following is the formula for calculating abnormal return:

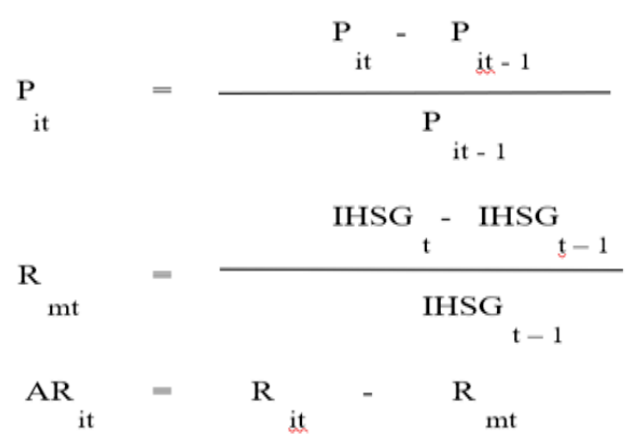

Where:

ARit: Abnormal Return for company I on day-t.

Rit: Daily return on company I on day-t.

Rm: Return of market index on day-t.

Pit: Share price of company I on time t-1.

IHSGt: Combined Share Price Index on time t-t.

IHSGt-1: Combined Share Price Index on time t-1.

\section{Independent Variable}

Independent variable in this research is implementation of CSR as reflected in the disclosure of CSR information in company annual report or CSR disclosure index (CSRI). then the measuring of CSRI variable is using content analysis that measures variety of CSRI. Content analyst is one of the methods of CSR measuring which have been used a lot in the previous researches. The measuring instrument of CSRI which will be used in this research refers to instrument as used by Sembiring (2005) which has grouped CSR information into 7 (seven) categories: environment, energy, manpower, product, community involvement, and public. Total item of CSR is ranging between 63 up to 78, defending on the type of industry/company.

\section{Control Variable}

Even though it is found some variables which are predicted for being able to influence the response against profit, but this research only use 2 control variables, namely BETA which constitutes the proxy of risk and price to book value (PBV) which constitutes the proxy of growth opportunities. BETA is predicted for having negative influence against ERC, whereas PBV is predicted to have positive influence against ERC. Scott (2000).

\section{Determining Research Sample}

Determining member of sample in this research shall use justified purposive sampling which mean member of sample is determined based on certain criteria. The sample criteria in this research are: 
Impact of Corporate Social Responsibility Disclosure to Stockprice of Banking and Mining Industry Listed at Indonesia Stock Exchange (IDX)

- Member of sample in this research is listed public company which is included in the group of LQ45 index of year 2006/2007, as contained in the list of LQ45 public companies based on the decision of capital market authorities/Bapepam.

- Member of sample has never been delisting from Indonesia Stock Exchange (BEI), in the period of two years consecutively.

- Member of sample shall issue annual report which is audited by public accountant office and preparing disclosure on the implementation of corporate social responsibility (CSR).

\section{RESEARCH MODEL}

\section{Model 1 (Without Control Variable)}

CAR $=$ b0 + b1UE, b2CSRI + b3UE*CSRI $+\varepsilon$

\section{Model 2 (With Control Variable)}

$\mathrm{CAR}=\mathrm{B} 0+\mathrm{b} 1 \mathrm{UE}+\mathrm{b} 2 \mathrm{CSRI}+\mathrm{b} 3 \mathrm{BETA}+\mathrm{b} 4 \mathrm{PBV}+\mathrm{b} 5 \mathrm{UE}^{*} \mathrm{CSRI}+\mathrm{b} 6 \mathrm{UE}^{*} \mathrm{BETA}+\mathrm{b} 7 \mathrm{UE} * \mathrm{PBV}+\varepsilon$

\section{Remarks}

CAR: Daily Cumulative Abnormal Return of company for 15 months starting from January 1, 2006.

UE: Unexpected earnings of company which is calculated by using the assumption of random walk (profit before extraordinary post of year 2006 deducted with profit before extraordinary post of year 2005), and implemented with company profit in the initial period.

CSRI: Corporate social disclosure index (measuring the type of CSR as disclosed by the company in its annual report).

BETA: Corrected BETA as obtained from ICMD database and PRPM which constitutes proxy of risk.

PBV: Price to book value ratio which constitutes proxy of company growth.

UE*CSRI: Interaction of UE and CSRI variables.

UE*BETA: Interaction of UE and BETA variables.

UE*PBV: Interaction of UE and PBV variables.

$\varepsilon$ : error term

If the level of CSR information disclosure is influencing informativeness from earnings, or if CSR information is influencing ERC, then it is predicted interaction coefficient between variable of unexpected return (UE) and CSRI (b3 in model 1 and b5 in model II) from Model I will be significant and having negative signed; Whereas for seeing the influence of control variables (BETA and PBV) against ERC, then it is seen consecutively the significance and direction of coefficient b6 and b7 in Model II

\section{RESULT AND DISCUSSION}

\section{Hypothesis Testing}

Determination Coefficient (R2 Testing and Adjusted R2)

Table1. Result of $R^{2}$ Test and Adjusted $R^{2}$

\begin{tabular}{|c|c|c|}
\hline Model & $\boldsymbol{R}^{\mathbf{2}}$ & ${\text { Adjusted } \boldsymbol{R}^{\mathbf{2}}}^{-0,040}$ \\
\hline 1. & 0,068 & $-0,098$ \\
\hline 2. & 0,167 & $-0,098$ \\
\hline
\end{tabular}


Impact of Corporate Social Responsibility Disclosure to Stockprice of Banking and Mining Industry Listed at Indonesia Stock Exchange (IDX)

Based on the result of regression test above it is known that regression Model 1 is found R2 value amounting to 0.08 , which means variation in the variables of UE, CSRI, and UE*CSRI can explain variables in CAR variable amounting to $6.8 \%$ whereas the remaining can be explained by other factors which are not taken part in the research. In regression Model 2 it is acquired R2 value amounting to 0.167 , which means the variants in variables UE, CSRI, BETA, PBV, UE*CSRI, UE*BETA, and UE*PBV may explain the variation in variable CAR amounting to $16.7 \%\left(0.167^{*} 100 \%\right)$ whereas the remaining can be explained by other factors which are not taken part in the model.

\section{F Test (Simultaneous Testing)}

This testing is applied for testing whether collectively the whole independent variables have significant impact against dependent variable.

Table2. Result of F Test (Simultaneous Test)

\begin{tabular}{|c|c|c|}
\hline Model & $\boldsymbol{F}$ & Sig. \\
\hline 1. & 0,627 & 0,604 \\
\hline 2. & 0,631 & 0,726 \\
\hline
\end{tabular}

Hypothesis Testing (F Test) - Model 1

Hypothesis (Ha1) is stated that "UE and CSRI has an significant influence on CAR without control variable (BETA correction and ratio of price-to-book-value PBV ratio)". Based on the result of F-Test Model 1 above, it is known that the value of significant value amounting to 0.604 is more than 0.05 , then Ho is accepted which means UE, CSRI and UE*CSRI collectively do not influence against CAR.

\section{Hypothesis Testing (F Test) - Model 2}

Hypothesis (Ha4) is stated that "UE and CSRI has an significant influence on CAR by including control variable (BETA correction and ratio of price-to-book-value PBV ratio)". Based on the result of F-Test Model 2 above as mentioned in Table 2, it is known that the significant value amounting to 0.726 is more than 0.05 , then Ho is accepted which means UE, CSRI, BETA, PBV,UE*CSRI, UE*BETA and UE*PBV collectively do not influence against CAR.

\section{t-Test (Partial Testing)}

Partial testing ( $t$-Test) is applied for testing whether individually independent variable has significant impact against dependent variable

Table3. Result of Test Model I

\section{Coefficients}

\begin{tabular}{|ll|r|r|r|r|r|}
\hline \multirow{2}{*}{ Model } & \multicolumn{2}{|c|}{$\begin{array}{c}\text { Unstandardized } \\
\text { Coefficients }\end{array}$} & $\begin{array}{c}\text { Standardized } \\
\text { Coefficients }\end{array}$ & \multicolumn{1}{c|}{} \\
\cline { 3 - 4 } & \multicolumn{1}{|c|}{$\mathrm{B}$} & \multicolumn{1}{c|}{ Std. Error } & \multicolumn{1}{c|}{ Beta } & \multicolumn{1}{c|}{ Sig. } \\
\hline 1 & (Constant) & -.467 & 2.540 & & -.184 & .856 \\
& UE & 3.266 & 3.642 & 6.359 & .897 & .378 \\
& CSRI & .150 & .112 & .290 & 1.336 & .193 \\
& UE*CSRI & -.122 & .136 & -6.408 & -.902 & .375 \\
\hline
\end{tabular}

a. Dependent Variable: CAR 
Impact of Corporate Social Responsibility Disclosure to Stockprice of Banking and Mining Industry Listed at Indonesia Stock Exchange (IDX)

\section{Model of Regression 1}

\section{CAR $=-0.467+3.266$ UE + 0.150 CSRI -0.122 UE*CSRI +}

Based on the result of t-Test on Table 3 above it is found that the constant variable has negative coefficient amounting to -0.467 which means if other variable is deemed constant, then CAR is undergoing decrease amounting to -0.467 . Such constant influence is not significant because the probability value amounting to 0.856 is more than 0.05 .

Hypothesis (Ha2) is stated that "UE has an significant influence on CAR without control variable (BETA and price-to-book-value PBV ratio)". Based on Table 3, above, it is known that coefficient of variable UE is positive amounting to 3.266, which means its coefficient 1 in UE will increase CAR amounting to 3.266. However the influence of UE is not significant because of the result of t-Test in table 3 above it is known that the significance of variable UE amounting to 0.378 is more than 0.05 , then Ho is accepted which means there is no significant impact of variable UE against variable CAR.

Hypothesis (Ha3) is states that "CSRI has an significant influence on CAR without control variable (BETA and price-to-book-value PBV ratio)". Based on Table 3, above, it is known that coefficient of variable CSRI is positive amounting to 0.150 , which means its increase of 1 in CSRI will increase CAR amounting to 0.150 . However, the influence of CSRI is notsignificant because of the result of t-Test in Table 3 above it is known that the significance of variable CSRI amounting to 0.193 is more than 0.05 , which means Ho is accepted which means there is no significant impact of variable CSRI against variable CAR.

\section{Equity Model of Regression II}

Table4. Result of $t$ - Test Model 2

\section{Coefficients $^{a}$}

\begin{tabular}{|c|c|c|c|c|c|c|}
\hline \multirow{2}{*}{\multicolumn{2}{|c|}{ Model }} & \multicolumn{2}{|c|}{$\begin{array}{c}\text { Unstandardized } \\
\text { Coefficients }\end{array}$} & \multirow{2}{*}{$\begin{array}{c}\text { Standardized } \\
\text { Coefficients } \\
\text { Beta } \\
\end{array}$} & \multirow[b]{2}{*}{$\mathrm{t}$} & \multirow[b]{2}{*}{ Sig. } \\
\hline & & $\mathrm{B}$ & Std. Error & & & \\
\hline \multirow[t]{8}{*}{1} & (Constant) & 2.987 & 5.912 & & .505 & .618 \\
\hline & UE & 5.569 & 6.015 & 10.841 & .926 & .365 \\
\hline & CSRI & .074 & .128 & .143 & .580 & .568 \\
\hline & BETA & -31.209 & 57.032 & -.127 & -.547 & .590 \\
\hline & PBV & .199 & .387 & .116 & .515 & .612 \\
\hline & UE*CSRI & -.018 & .155 & -.966 & -.119 & .907 \\
\hline & UE*BETA & -54.058 & 51.777 & -10.184 & -1.044 & .308 \\
\hline & UE*PBV & .154 & .468 & .310 & .329 & .745 \\
\hline
\end{tabular}

a. Dependent Variable: CAR

\section{CAR = 2.987 + 5.569UE + 0.074CSRI - 31.209BETA + 0.199 PBV -0.018 UE*CSRI - 54.058 UE*BETA + 0.154 $\mathrm{UE} * \mathrm{PBV}+\dot{\varepsilon}$}

Based on the result of t-Test above it is known that constant variable has positive coefficient amounting to 2.987, which means if other variable is deemed constant then CAR is undergoing increase amounting to 2.987. Such constant impact is not significant because the probability value amounting to 0.618 is more than 0.05 .

Hypothesis (Ha5) is stated that "UE has an significant influence on CAR by including control variable (BETA and price-to-book-value PBV ratio)". Based on the result of hypothesis testing in Table 4 above, it is known that coefficient of variable UE is positive amounting to 5.569, which means each increase of 1 in UE will increase CAR amounting to 5.569. The impact of UE is not significant because of the result of t-Test above it is known that thesignificance of variable UE amounting to 0.365 is more than 0.05 , then Ho is accepted which means there is no significant impact of variable UE against variable CAR.

American Research Journal of Business and Management 
Impact of Corporate Social Responsibility Disclosure to Stockprice of Banking and Mining Industry Listed at Indonesia Stock Exchange (IDX)

Hypothesis (Ha6) is stated that "CSRI has an significant influence on CAR by including control variable (BETA and price-to-book-value PBV ratio)". Based on the result of hypothesis testing in Table 4 above, it is known that coefficient of variable CSRI is positive amounting to 0.074 , which means each increase of 1 in CSRI will increase CAR amounting to 0.074 . The impact of CSRI is not significant because of the result of t-Test it is known that the significance of variable CSRI amounting to 0.568 is more than 0.05 , then Ho is accepted which means it is found significant impact of variable CSRI against variable CAR.

Hypothesis (Ha4) is stated that "UE and CSRI has an significant influence on CAR by including control variable (BETA correction and ratio of price-to-book-value PBV ratio)". Based on the result of hypothesis testing in Table 4 above, it is known that coefficient of variable UE*CSRI is negative amounting to -0.018 , which means each increase of 1 in CSRI will decrease CAR amounting to -0.018. The impact of UE*CSRI is not significant because of the result of $\mathrm{t}$-Test it is known that the significance of variable UE*CSRI amounting to 0.907 is more than 0.05 , then Ho is accepted which means it is not found any significant impact of variable UE*CSRI against variable CAR.

\section{CONCLUSION}

Research of first model which has not included control variable BETA correction and price to book value (PBV), is acquired a result that it is not found significant impact from variables UE and CSRI collectively against variable CAR without control variable BETA correction and ratio price-to book-value (PBV), this matter is known from significant value amounting to 0.604 more than 0.05 . Research of second model which has included control variable BETA and ratio of price-to-book-value (PBV), is acquired a result that it is not found any significant impact from variables UE and CSRI collectively against variable CAR by having included control variable BETA correction and ratio of price-to-book-value (PBV), this matter is known from the significant value amounting to 0.726 more than 0.05 . So, based on the two matters as above mentioned, it can be concluded that the disclosure of implementation ofcorporate social responsibility (CSR) has no impact against the price of public company share in Indonesia Stock Exchange.

\section{IMPLICATION OF RESEARCH}

This research may provide contribution to the stakeholders concerning the importance of implementation of company social responsibility constitutes very important matters even though empirically it does not have direct impact against the public company share price in Indonesia Stock Exchange. For investors and potential investors, you have to be more careful because this research is not able to prove the influence from the implementation of social responsibility against share price; however, the investor is better to choose shares of public companies which have implemented social responsibilities. For further aim of research, it is expected to add the coverage of respondents by means of extending the period of observation and classifying the category of company in CSR implementation.

\section{REFERENCES}

Alexander, Gordon J., and Rogene A. Buchholz (1978), "Corporate Social Responsibility and Stock Market Performance", The Academy of Management Journal, Vol. 21, No. 3 (Sep), pp. 479 - 486.

Billings, Bruce K. (1999), "Revisiting the Relation between the Default Risk of Debt and the Earnings Response Coefficient", The Accounting Review, Vol. 74, No. 4. (Oct), pp. 509 - 522.

Core, John E. (2001), "A Review of the Empirical Disclosure Literature: Discussion”, Journal of Accounting and Economics, 31, pp. $441-456$.

American Research Journal of Business and Management

Page 7 
Impact of Corporate Social Responsibility Disclosure to Stockprice of Banking and Mining Industry Listed at Indonesia Stock Exchange (IDX)

Cowen, S., Ferreri, L.D., dan L.D. Parker (1987), "The Impact of Corporate Characteristics on Social Responsibility Disclosure: A Typology and Frequency-Based Analysis", Accounting, Organization and Society, Vol. 12, No. 2, pp. $111-122$.

Guthrie, J. (1982), "Social Accounting in Australia - Social Responsibility Disclosures in the Top 150 Listed Australian Companies, 1980 Annual Reports".

Guthrie, J. and L.D. Parker (1990), "Corporate Social Disclosure Practice: A Comparative International Analysis”, Advances in Public Interest Accounting, Vol. 3, pp. 159 - 175.

Haniffa, R.M., dan T.E. Cooke (2005), "The Impact of Culture and Governance on Corporate Social Reporting", Journal of Accounting and Public Policy 24, pp. 391 - 430.

Healy, Paul M., and Krishna G. Palepu (2001), "Information asymmetry, corproate disclosure, and the capital markets: A review of the empirical disclosure literature", Journal of Accounting and Economics, 31, pp. 405 -440 .

Kiroyan, Noke (2006), "Good Corporate Governance (GCG) dan Corporate Social Responsibility (CSR) AdakahKaitan di AntaraKeduanya?", Economics Business Accounting Review, Edisi III, September-Desember 2006, Hal. 45 - 58.

Kothari, S.P., and Jerold L. Zimmerman (1995), "Price and Return Models", Journal of Accounting and Economics, 20, pp.155 - 192.

Lev, Baruch (1989), "On the Usefulness of Earnings and Earnings Research: Lessons and Directions from Two Decades of Empirical Research", Journal of Accounting Research, Vol. 27, pp. 153 - 192.

Pfeiffer, Jr., Ray J., Pieter T. Elgers, May H. Lo, and Lynn L. Rees (2001), "Additional Evidence on the Incremental Information Content of Cash Flows and Accruals: The Impact of Errors in Measuring Market Expectations", The Accounting Review, vol. 73, No. 3 (Jul), PP. 373 - 385.

Roberts, R.W. (1992), "Determinants of Corporate Social Responsibility Disclosures: An Application of Stakeholder Theory", Accounting, Organization and Society, Vol. 17, No. 6, pp. 595 - 612.

Sayekti, Yosefa (1994), Corporate Social Responsibility Disclosures: 'State-of-the-Art' in Australia, Thesis, Unpublished, University of South Australia, Adelaide.

Scott, William R. (2000), Financial Accounting Theory, $2^{\text {nd }}$ edition, Prentice-Hall Canada Inc., Scarborough, Ontario.

Citation: Solihin, Etty Murwaningsari. "Impact of Corporate Social Responsibility Disclosure to Stockprice of Banking and Mining Industry Listed at Indonesia Stock Exchange (IDX)" American Research Journal of BusinesS and Management. 2018; 4(1): 1-8.

Copyright (c) 2018 Solihin, Etty Murwaningsari. This is an open access article distributed under the Creative Commons Attribution License, which permits unrestricted use, distribution, and reproduction in any medium, provided the original work is properly cited. 